Zagazig J. Agric. Res., Vol. 43 No. (4) 2016

http:/www.journals.zu.edu.eg/journalDisplay.aspx?Journalld=1\&queryType=Master

\title{
PERFORMANCE EVALUATION OF A FARM RESIDUES CHOPPING MACHINE
}

\author{
Mona N.Sh. Radwan", M.M. Morad, M.M.A. El-Sharabasy and M.M. Badr \\ Agric. Eng. Dept., Fac. Agric., Zagazig Univ., Egypt
}

\begin{abstract}
Experiments were carried out to evaluate the performance of a farm residues chopping machine so as to use final product for producing animal feed. The performance of the chopping machine was studied under three different types of farm residues [rice straw, sweet potatoes vines and peanut vines], four different cutting drum speeds and four different feed rates. The performance of the chopping machine was evaluated taking into consideration machine productivity, required power, specific energy, operational cost and criterion cost. The experimental results reveal that the optimum values of machine productivity were $258.26,339.16$ and $282.38 \mathrm{~kg} / \mathrm{hr}$; the optimum values of the required power were $3.17,2.85$ and $2.90 \mathrm{~kW}$; the optimum values of the specific energy were 12.27 , 8.40 and $10.27 \mathrm{~kW} . \mathrm{hr} / \mathrm{Mg}$; the optimum values of operational cost were $91.88,69.97$ and 84.04 $\mathrm{LE} / \mathrm{Mg}$ and the optimum values of criterion cost were $102.38,81.49$ and $93.32 \mathrm{LE} / \mathrm{Mg}$ for rice straw, sweet potatoes vines and peanut vines, respectively. The mentioned optimum values were achieved under the following conditions: cutting drum speed of about $1520 \mathrm{rpm}$ corresponding to $(33.41 \mathrm{~m} / \mathrm{sec}$.) for different farm residues with adjusting feed rates at 283.15, 400 and $320 \mathrm{~kg} / \mathrm{hr}$., for rice straw, sweet potatoes vines and peanut vines, respectively.
\end{abstract}

Key words: Chopping, rice straw, sweet potatoes vines, peanut vines.

\section{INTRODUCTION}

Crop residues are one of the most critical problems which face the Egyptian farmer specially after harvesting. In Egypt, there are about 40 million $\mathrm{Mg}$ yearly of the field raw material. The national income might be increased with 4.6 billion LE/year if field raw materials are recycled. Egyptian farmer burn rice straw as a way for disposing it and to save time to prepare the soil for next crops .This habit results in a vast loss of energy accompanied with direct negative effect on both human health and environment. Moreover, the traditional way of storing the crop residues in the farms and houses roofs gives unlimited chance for the possibility of fire corruption of these residues. To solve this problem, it must be cut the plant residues into pieces using chopping machine to minimize their size and volume to facilitate handling, transporting and reduce storage space. Then chopped crop residues can be used in different purposes such as un-traditional fodder for feeding animals, compost to be added to the soil to help increasing soil fertility and improve its physical properties and biogas as a source of energy. In Egypt, different chopping machines are used, some of these machines are imported and the other are locally manufactured. In both cases, such care had been taken to improve the performance of these machines taking into consideration machine productivity, total losses, energy and cost requirement. Mohamed et al. (2001) developed and evaluated a rice straw chopper. The results indicated that the productivity of the developed machine was 0.95 $\mathrm{Mg} / \mathrm{hr}$., at $2000 \mathrm{rpm}$ rotor speed and the cutting lengths of $(1-9 \mathrm{~cm})$ reached $95.25 \%$ from the total amount of cutting residue. El-Iraqi and ElKhawaga (2002) designed a cutting machine for

\footnotetext{
* Corresponding author: Tel. : +201093531796

E-mail address: monanasr.19@yahoo.com
} 
chopping rice straw and corn stalks. They found that the maximum percentages of $<5 \mathrm{~cm}$ cutting length of 87.80 and $92.00 \%$ were obtained for rice straw and corn stalks residues, respectively at cutting speed of $10.09 \mathrm{~m} / \mathrm{sec}$, feeding rate of $0.771 \mathrm{Mg} / \mathrm{hr}$., and knife clearance of $1.5 \mathrm{~mm}$, maximum values of power consumption of 4.90 and $4.76 \mathrm{~kW}$ were obtained at feeding rate of $0.771 \mathrm{Mg} / \mathrm{hr}$., and cutting speed of $10.09 \mathrm{~m} / \mathrm{sec}$., with knife clearance of $4.5 \mathrm{~mm}$ for cutting rice straw and corn stalks, respectively. They recommended using the designed cutting machine for cutting rice straw and corn stalks residues at $0.771 \mathrm{Mg} / \mathrm{hr}$., feeding rate 10.09 $\mathrm{m} / \mathrm{sec}$., cutting speed with $1.5 \mathrm{~mm}$ knife clearance. Younis et al. (2002) developed chopping machine and used it for cutting residues of rice, cotton and corn stalks. They found that the maximum required power and consumed energy of, $11.77 \mathrm{~kW}$ and 12.99 $\mathrm{kW} . \mathrm{hr} . \mathrm{Mg}$ were found at rotor speeds of 2200 and $1600 \mathrm{rpm}$, respectively. The increasing of rotor speed from 1600 to $2000 \mathrm{rpm}$ caused a decrease of consumed energy by $17.11 \%$. While the increasing of rotor speed from 2000 to 2200 rpm caused an increase of consumed energy by $12.9 \%$. Lotfy (2003) evaluated a machine powered by electric motor for chopping agricultural residues. He found that the machine output values were $(1.822,2.128$ and 0.967 $\mathrm{Mg} / \mathrm{hr})$, average cut length values were $(2.8,2.5$ and $2.6 \mathrm{~cm}$ ), energy requirements values were $(12.14, \quad 11.45$ and 11.03 kW.hr. $/ \mathrm{Mg}$ ) and operational costs were $(8.13,6.80$ and $7.07 \mathrm{LE} /$ $\mathrm{Mg}$ ) for cutting rice straw, cotton stalk and corn stalks, respectively under $43.35 \mathrm{~m} / \mathrm{sec}$, cutting speed and $2 \mathrm{~m} / \mathrm{sec}$., feeding speed for feeding animals. He added that the machine output values were $(2.037,2.359$ and $2.184 \mathrm{Mg} / \mathrm{hr}$ ), cut length values were $(4.8,4.2$ and $4.9 \mathrm{~cm})$, energy requirements values were $(11.74,10.95$ and $10.52 \mathrm{~kW} . \mathrm{hr} . \mathrm{Mg}$ ) and operating costs were (6.80, 5.74 and $6.07 \mathrm{LE} / \mathrm{Mg}$ ) for cutting the previously mentioned crop residues, respectively under the same conditions and $2.5 \mathrm{~m} / \mathrm{sec}$., feeding speed for composting. El-Khateeb (2007) mentioned that increasing the cutter head speed from 22.1 to $35.3 \mathrm{~m} / \mathrm{sec}$ tends to increase percentage of chopping length 0.5 to $2.0 \mathrm{~cm}$, from 50 to $60 \%$, degree of destruction, from 28.7 to $38.2 \%$, machine productivity from 1.32 to $2.81 \mathrm{Mg} / \mathrm{hr}$., useful power from 2.19 to 3.86 $\mathrm{kW}$ with decreasing the unit energy required from 1.87 to $1.37 \mathrm{~kW} . \mathrm{hr} . / \mathrm{Mg}$ and chopping machine cost from 16.33 to $7.22 \mathrm{LE} / \mathrm{Mg}$ at number of knives of 2 and corn stalk moisture content of $65.0 \%$. Morad et al. (2007) investigated the performance of crop residues chopping machine during cutting some farm residues in terms of percentage of cutting lengths, energy and cost as a function of change in chopper drum speed, material feed rate and moisture content. They recommended to use the chopping machine under chopper rotating speed of $51.13 \mathrm{~m} / \mathrm{sec}$., also under feed rates of 0.45 , 1.03 and $0.53 \mathrm{Mg} / \mathrm{hr}$., for rice straw, corn stalks and sugar cane residues, respectively. They also recommended to adjust moisture contents at 5.5, 83 and $11 \%$ for the same previous residues, respectively.

Solomon-Tekeste (2012) developed an engine-driven chopper for chopping the crop and hay. The machine was design with the following main components: feed hopper, rotating drum with swinging knives, casing with fixed knives welded on it, a screen and stands. The machine performance was conducted using three levels of drum speeds: 960,1200 and 1400 $\mathrm{rpm}$, and three feed rates: 420, 540 and 660 $\mathrm{kg} / \mathrm{hr}$. The test result showed that the optimum drum speed and feed rate values for both corn stalk and grass were $1200 \mathrm{rpm} 540 \mathrm{~kg} / \mathrm{hr}$, respectively. The average size reduction percentages using these optimum combinations were $92.0 \%$ and $79.5 \%$ for corn stalk and grass, respectively. The machine performed well with output rate ranging from 420 to $660 \mathrm{~kg} / \mathrm{hr}$.

So, such care had to be taken to evaluate and operate the chopping machine for cutting farm residues to be suitable for producing animal feed. Thus, the objectives of the present study are to:

- Produce a low cost animal feed by processing farm residues.

- Optimize some operating parameters: (type of residues, cutting drum speed and feed rate) affecting the performance of chopping machine.

- Evaluate the chopping machine from the economic stand point. 


\section{MATERIALS AND METHODS}

The experiments were conducted at Department of Agricultural Engineering, Faculty of Agriculture, Zagazig University to evaluate the performance of the chopping machine for cutting rice straw, sweet potatoes vines and peanut vines so as to use the final product in producing animal feed.

\section{Materials}

\section{The used crop residues}

Three crop residues were used in the study (rice straw, sweet potatoes vines and peanut vines). Some physical properties of the used residues were illustrated in Table 1.

\section{The chopping machine}

The chopping machine suitable for cutting rice straw, sweet potatoes vines and peanut vines consists of the following main parts as shown in Fig. 1.

\section{Feed inlet}

A small opening of $34 \mathrm{~cm}$ in width and $7 \mathrm{~cm}$ in height. The feed inlet has also three inclination sides with total height of $48 \mathrm{~cm}$.

\section{Feeding drums}

The chopping machine was provided with two feeding drums having dimension $7 \mathrm{~cm}$ in diameter and $34 \mathrm{~cm}$ in length.

\section{Chopping drum}

The chopping drum is fixed at horizontal shaft. The shaft is made of steel with $45 \mathrm{~cm}$ in diameter and $43 \mathrm{~cm}$ in length. The shaft is laid on two horizontal bearings. Three steel shears were fixed on the shaft. Each one ends with a sharp blade having dimensions $35 \mathrm{~cm}$ in length, $6 \mathrm{~cm}$ in width and $3 \mathrm{~mm}$ in thickness. The sharp blade was fixed on the steel shear using four Hex. The inclination chopping blades play as a centrifugal fan to move the chopping materials towards the outlet.

\section{Opening outlet}

The opening outlet dimensions are $38 \mathrm{~cm}$ in width and $24 \mathrm{~cm}$ in height.

\section{Power source}

The unit was powered by an electric motor $5.5 \mathrm{~kW}(7.48 \mathrm{hp})$ at a rated speed of $1450 \mathrm{rpm}$.

\section{Frame}

The frame dimensions are $80 \mathrm{~cm}$ in length, $80 \mathrm{~cm}$ in height, and $54 \mathrm{~cm}$ in width.

\section{Methods}

\section{Experimental conditions}

The performance of the chopping machine was experimentally measured under the following parameters:

- Three different types of farm residues (rice straw, sweet potatoes vines, peanut vines).

- Four different cutting drum speeds of 25.28, $29.19,33.41$ and $35.78 \mathrm{~m} / \mathrm{sec}$., corresponding to $(1150,1328,1520$ and $1628 \mathrm{rpm})$, respectively.

- Four different material feed rates of (159.49, $201.60,283.15$ and $336 \mathrm{~kg} / \mathrm{hr}$.), (322.39, 400, 502.33 and $553.85 \mathrm{~kg} / \mathrm{hr}$.) and $(165.52,240$, 320 and $389.19 \mathrm{~kg} / \mathrm{hr}$.) for rice straw, sweet potatoes vines and peanut vines.

All experiments were conducted under constant moisture contents of $(10.23,10.66$ and $11.24 \%$ w.b.) for the same farm residues.

\section{Measurements and determinations}

Evaluation of the performance of the chopping machine for cutting rice straw, sweet potatoes vines and peanut vines were based on the following indicators:

\section{Machine productivity (MP)}

The machine productivity was calculated from the following equation:

$$
\mathrm{MP}=\frac{\mathrm{W}}{\mathrm{t}}
$$

Where

$\mathrm{MP}=$ machine productivity, $\mathrm{kg} / \mathrm{hr}$.

$\mathrm{W}=$ mass of chopped residues, $\mathrm{kg}$.

$\mathrm{t}=$ machine operating time, $\mathrm{hr}$.

\section{Required power}

The power required was calculated knowing shaft speed (rpm), Ampere (I) and the voltage (v) values using the following formula (Ibrahim 1983):

$$
\mathrm{P}=\mathrm{I} \times \mathrm{V} \times \cos \theta
$$


Table 1. Some physical properties of the experimental crop residues

\begin{tabular}{lccc}
\hline Physical property & Rice straw & Sweet potatoes vines & Peanut vines \\
\hline Stem diameter, mm & 2.83 & 3.90 & 2.79 \\
Stem length, cm & 120 & 124.37 & 57.26 \\
Mass of 20 stalk, g & 58.6 & 483.4 & 54 \\
Number of branches & 0 & 0 & 19 \\
Density of chopped resides, $\mathbf{~} \mathbf{~ g / \mathbf { m } ^ { \mathbf { 3 } }}$ & 67.05 & 157.95 & 76.14 \\
\hline
\end{tabular}
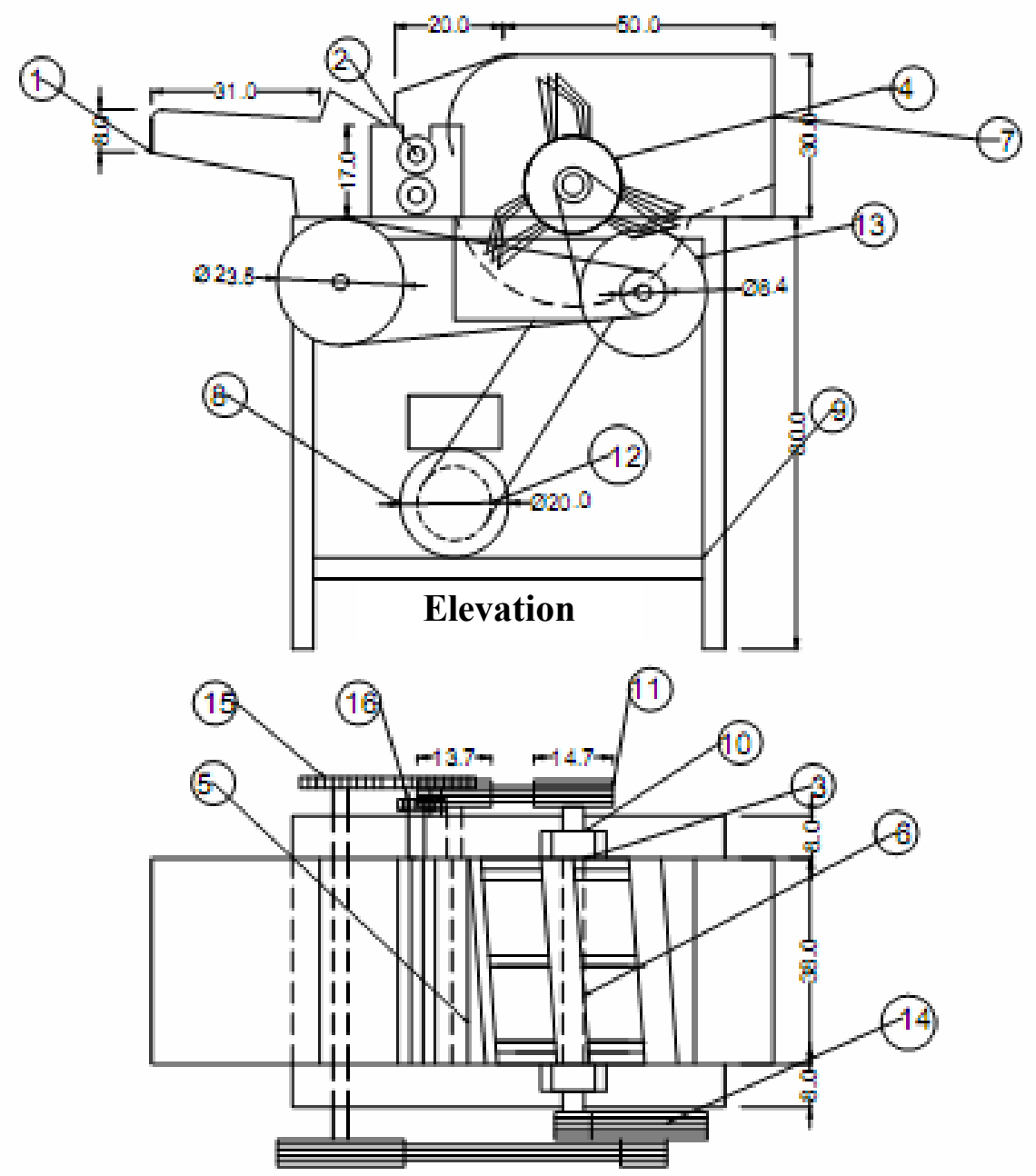

Plan

All dimension in , cm

\begin{tabular}{|c|c|c|c|c|c|}
\hline No. & Part name & No. off & No. & Part name & No. off \\
\hline 1 & Feed inlet & 1 & 9 & Main fram & 1 \\
\hline 2 & feed drum & 2 & 10 & Bearing & 8 \\
\hline 3 & chopping shaft & 1 & 11 & Pulley of chopping shaft & 2 \\
\hline 4 & chopping drum & 1 & 12 & Pulley of motor & 1 \\
\hline 5 & fixed knife & 1 & 13 & Driven pulley & 3 \\
\hline 6 & cutter head & 3 & 14 & V- Belt & 3 \\
\hline 7 & Opening out let & 1 & 15 & Drive Gear & 1 \\
\hline 8 & Electrical motor & 1 & 16 & Driven Gear & 6 \\
\hline
\end{tabular}

Fig. 1. Elevation and plan of the chopping machine 
Where:

$\mathrm{P}=$ Required power, $\mathrm{kW}$

$\mathrm{I}=$ current strength, Ampere

$\mathrm{V}=$ voltage, Volt $(220 \mathrm{v})$

$\operatorname{Cos} \Theta=$ power factor, Being equal to 0.96

$\Theta=$ phase angle between Vand I

\section{Specific energy}

Specific energy was estimated using the following formula:

$$
\mathrm{SE}=\frac{\mathrm{P}}{\mathrm{MP}}
$$

Where:

$\mathrm{SE}=$ specific energy, $\mathrm{kW} \cdot \mathrm{hr} / \mathrm{Mg}$

Operational cost LE/Mg

$$
\mathrm{OC}=\frac{\mathrm{MC}}{\mathrm{MP}}
$$

Where:

$\mathrm{OC}=$ operational cost, $\mathrm{LE} / \mathrm{Mg}$

$\mathrm{MC}=$ machine cost $\mathrm{LE} / \mathrm{hr}$.

The machine cost analysis was performed considering the conventional method of estimation both fixed and variable costs (Hunt, 1983).

\section{Criterion cost, $\mathrm{LE} / \mathrm{Mg}$}

The criterion cost required for the chopping operation was estimated using the following equation (Awady, 1982)

Criterion $\operatorname{cost}=$ operationa 1 cost + losses cost $(5)$

\section{RESULTS AND DISCUSSION}

The obtained results will be discussed under the following items:

\section{Influence of Cutting Drum Speed on the Machine Productivity at Different Feed Rates}

Representative values of machine productivity versus cutting drum speed at different feed rates for rice straw, sweet potatoes vines and peanut vines are given in Fig. 2. The results show that increasing drum speed increased machine productivity up to $1520 \mathrm{rpm}$; any further increase in drum speed up to 1628 rpm machine productivity will decrease.

Concerning rice straw, obtained results show that increasing drum speed from 1150 to 1520 rpm measured at different feed rates of 159.49 , 201.60, 283.15 and $336 \mathrm{~kg} / \mathrm{hr}$., increased machine productivity from 131.93 to 140.20 , from 168.75 to 188.72 , from 239.28 to 258.26 and from 279.92 to $315 \mathrm{~kg} / \mathrm{hr}$. The further increase in drum speed more than 1520 up to $1628 \mathrm{rpm}$ measured at the same previous feed rates, decreased machine productivity from 140.20 to 129.02 , from 188.72 to 168.47 , from 258.26 to 221.11 and from 315 to $267.22 \mathrm{~kg} / \mathrm{hr}$.

Respecting sweet potatoes vines, obtained results show that increasing drum speed from 1150 to $1520 \mathrm{rpm}$ measured at different feed rates of $322.39,400,502.33$ and $553.85 \mathrm{~kg} / \mathrm{hr}$, increased machine productivity from 198 to 257.14 , from 258.93 to 339.16 , from 313.04 to 422.61 and from 352.29 to $454.29 \mathrm{~kg} / \mathrm{hr}$. The further increase in drum speed more than 1520 up to $1628 \mathrm{rpm}$ measured at the same previous feed rates, decreased machine productivity from 257.14 to 241.72 , from 339.16 to 317.06 , from 422.61 to 393.46 and from 454.29 to 422.16 $\mathrm{kg} / \mathrm{hr}$.

Considering peanut vines, obtained results show that increasing drum speed from 1150 to $1520 \mathrm{rpm}$ measured at different feed rates of $165.52,240,320$ and $389.19 \mathrm{~kg} / \mathrm{hr}$, increased machine productivity from 105.40 to 131.60 , from 165.71 to 195.43 , from 232.50 to 282.38 and from 250.65 to $315 \mathrm{~kg} / \mathrm{hr}$. The further increase in drum speed more than 1520 up to $1628 \mathrm{rpm}$ measured at the same previous feed rates, decreased machine productivity from 131.60 to 118.40 , from 195.43 to 178.86 , from 282.38 to 226 and from 315 to $264.60 \mathrm{~kg} / \mathrm{hr}$.

Lower or higher values of cutting drum speed less or more than the optimum value tend to decrease machine productivity because the residues drop through the hold at the bottom of the feed drum that represents losses which decrease productivity. 
Rice straw

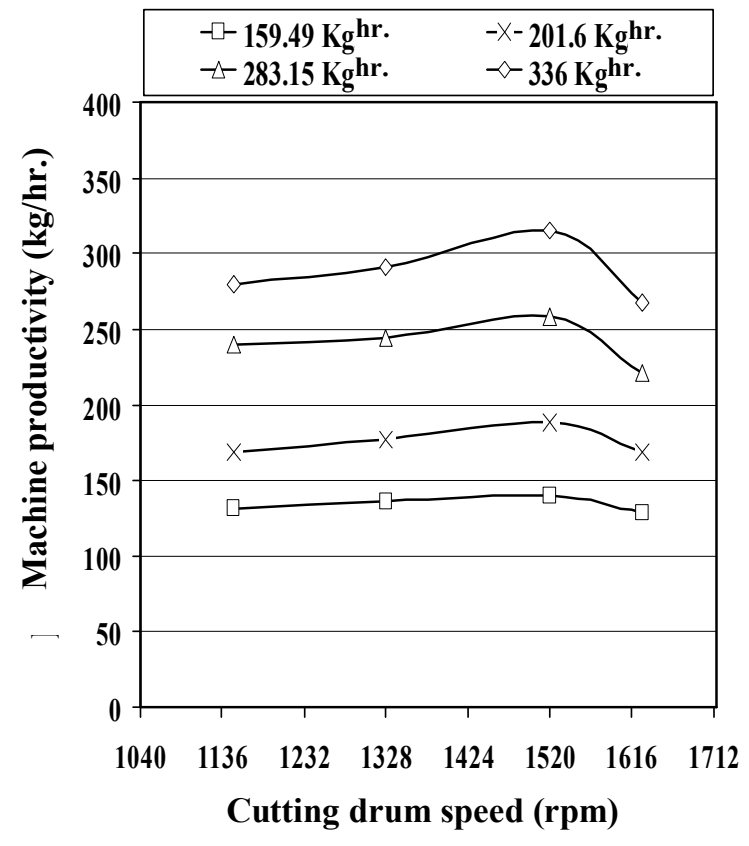

Sweet potatoes vines

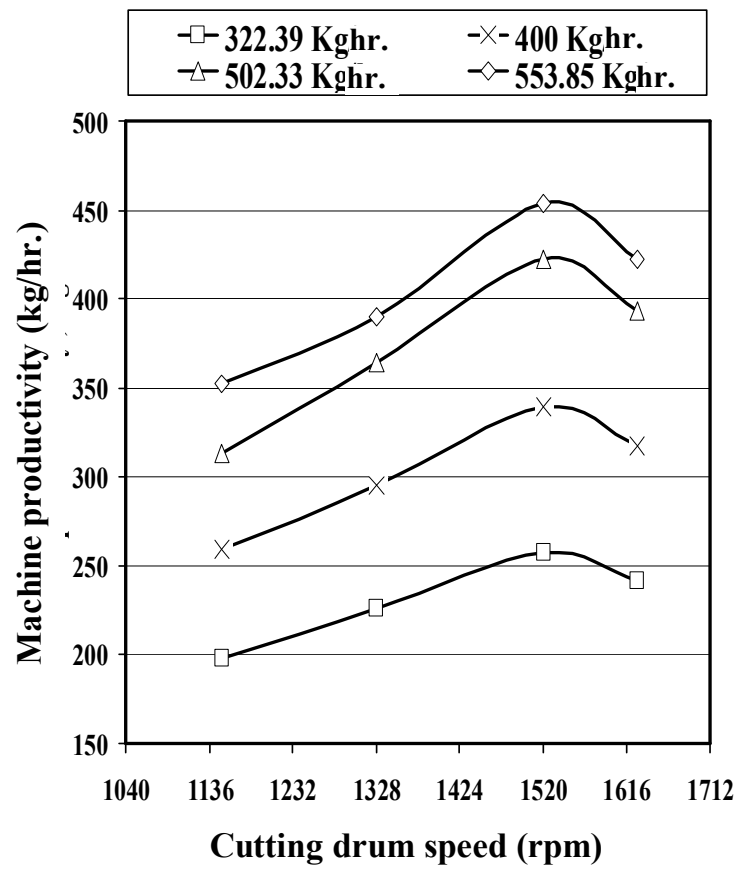

Peanut vines

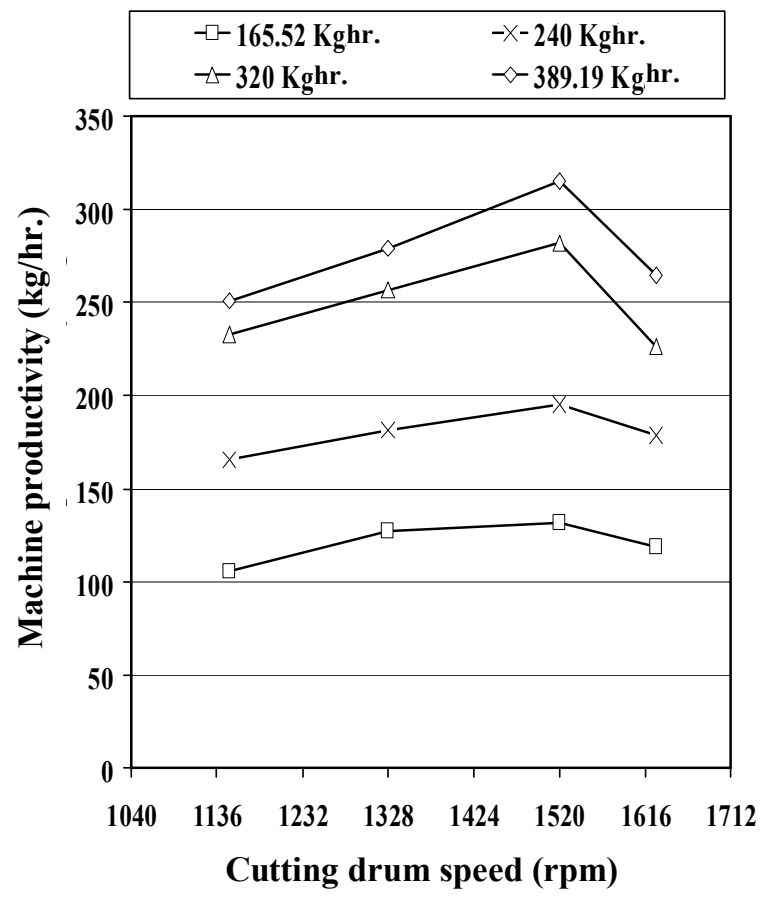

Fig.2. Effect of cutting drum speed on machine productivity at different feed rates for different crop residues 
Influence of Cutting Drum Speed on the Required Power and Specific Energy at Different Feed Rates

Representative values of both required power and specific energy versus cutting drum speed at different feed rates for rice straw, sweet potatoes vines and peanut vines are given in Fig. 3. Results obtained show that increasing drum speed increased required power and specific energy.

In relation to rice straw, obtained results show that increasing drum speed from 1150 to $1628 \mathrm{rpm}$ measured at different feed rates of $159.49,201.60,283.15$ and $336 \mathrm{~kg} / \mathrm{hr}$ increased required power from 1.74 to 3.27 , from 1.92 to 3.37, from 2.15 to 3.47 and from 2.35 to 3.84 $\mathrm{kW}$, also increased specific energy from 13.19 to 25.34 , from 11.38 to 20.00 , from 8.99 to 15.69 and from 8.40 to $14.37 \mathrm{~kW} . \mathrm{hr} . \mathrm{Mg}$, respectively.

In connection with sweet potatoes vines, obtained results show that increasing drum speed from 1150 to $1628 \mathrm{rpm}$ measured at different feed rates of $322.39,400,502.33$ and $553.85 \mathrm{~kg} / \mathrm{hr}$., increased required power from 1.57 to 2.41 , from 2.02 to 2.95 , from 2.15 to 3.40 and from 2.25 to $3.58 \mathrm{~kW}$, also increased specific energy from 7.93 to 9.97 , from 7.80 to 9.30 , from 6.87 to 8.64 and from 6.39 to 8.48 kW.hr./Mg, respectively.

Relating to peanut vines, obtained results show that increasing drum speed from 1150 to $1628 \mathrm{rpm}$ measured at different feed rates of $165.52,240,320$ and $389.19 \mathrm{~kg} / \mathrm{hr}$., increased required power from 1.55 to 2.20 , from 2.00 to 2.76, from 2.15 to 3.02 and from 2.23 to 3.20 $\mathrm{kW}$, also increased specific energy from 14.71 to 18.58 , from 12.07 to 15.43 , from 9.25 to 13.36 and from 8.90 to $12.09 \mathrm{~kW} . \mathrm{hr} . \mathrm{Mg}$, respectively.

The increase in required power and specific energy by increasing cutting drum speed at the same feeding drum speed is attributed to the increase of cutting blades knocking number in time unit on the residues, that tends to increase electric consumption and as a result required power. Specific energy increase could be due to the high increase in required power comparing with the low increase in the machine productivity.

\section{Influence of Cutting Drum Speed on Operational and Criterion Costs at Different Feed Rates}

Representative values of both operational and criterion costs versus cutting drum speed at different feed rates for rice straw, sweet potatoes vines and peanut vines are given in Fig. 4. Concerning rice straw, results show that increasing drum speed from 1150 to $1520 \mathrm{rpm}$ measured at different feed rates of 159.49, 201.60, 283.15 and $336 \mathrm{~kg} / \mathrm{hr}$., decreased operational cost from 179.87 to 169.26 , from 140.62 to 125.74 , from 99.17 to 91.88 and from 84.77 to $75.33 \mathrm{LE} / \mathrm{Mg}$, also decreased criterion cost from 185.69 to 174.39 , from 143.69 to 128 , from 111.22 to 102.38 and from 116.84 to 105.77 LE/Mg, respectively. The further increase in drum speed more than 1520 up to $1628 \mathrm{rpm}$ measured at the same previous feed rates increased operational cost from 169.26 to 183.92 , from 125.74 to 140.86 , from 91.88 to 107.32 and from 75.33 to $88.80 \mathrm{LE} / \mathrm{Mg}$, also increased criterion cost from 174.39 to 189.88 , from 128 to 144.19 , from 102.38 to 119.5 and from 105.77 to $122.08 \mathrm{LE} / \mathrm{Mg}$ respectively.

With respect to sweet potatoes vines, results show that increasing drum speed from 1150 to $1520 \mathrm{rpm}$ measured at different feed rates of $322.39, \quad 400, \quad 502.33$ and $553.85 \mathrm{~kg} / \mathrm{hr}$, decreased operational cost from 119.85 to 92.28 , from 91.65 to 69.97 , from 75.81 to 56.15 and from 67.36 to $52.24 \mathrm{LE} / \mathrm{Mg}$, also decreased criterion cost from 148.81 to 115.08 , from 109.41 to 81.49 , from 128.74 to 97.78 and from 159.30 to $134.59 \mathrm{LE} / \mathrm{Mg}$, respectively. The further increase in drum speed more than 1520 up to $1628 \mathrm{rpm}$ measured at the same previous feed rates increased operational cost from 92.28 to 98.17 , from 69.97 to 74.84 , from 56.15 to 60.31 and from 52.24 to $56.21 \mathrm{LE} / \mathrm{Mg}$, also increased criterion cost from 115.08 to 121.92 , from 81.49 to 87.83 , from 97.78 to 106.36 and from 134.59 to $143.17 \mathrm{LE} / \mathrm{Mg}$, respectively. 


\begin{tabular}{|ll|}
\hline Required power & Specific energy ------------ \\
\hline
\end{tabular}

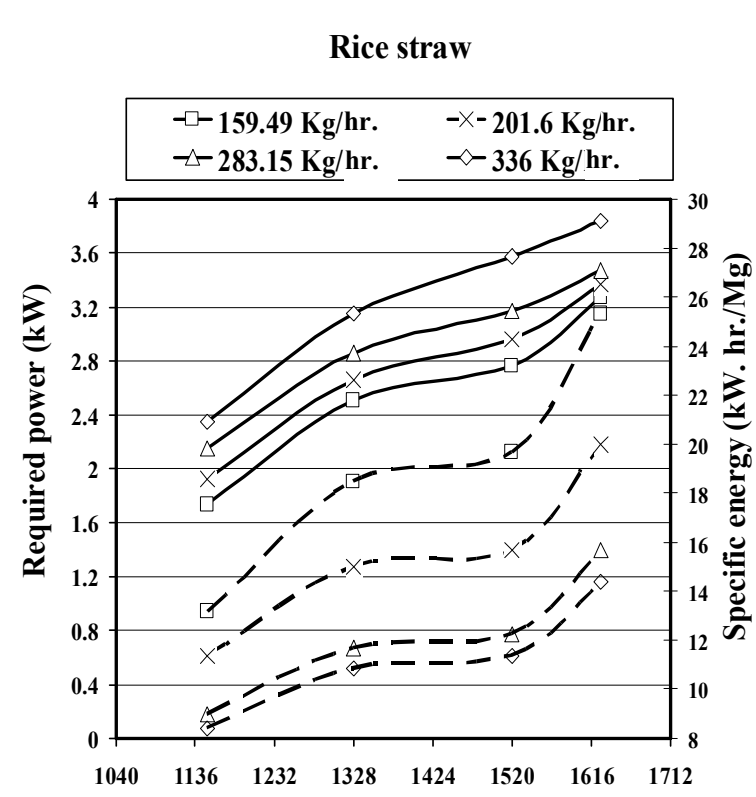

Cutting drum speed (rpm)

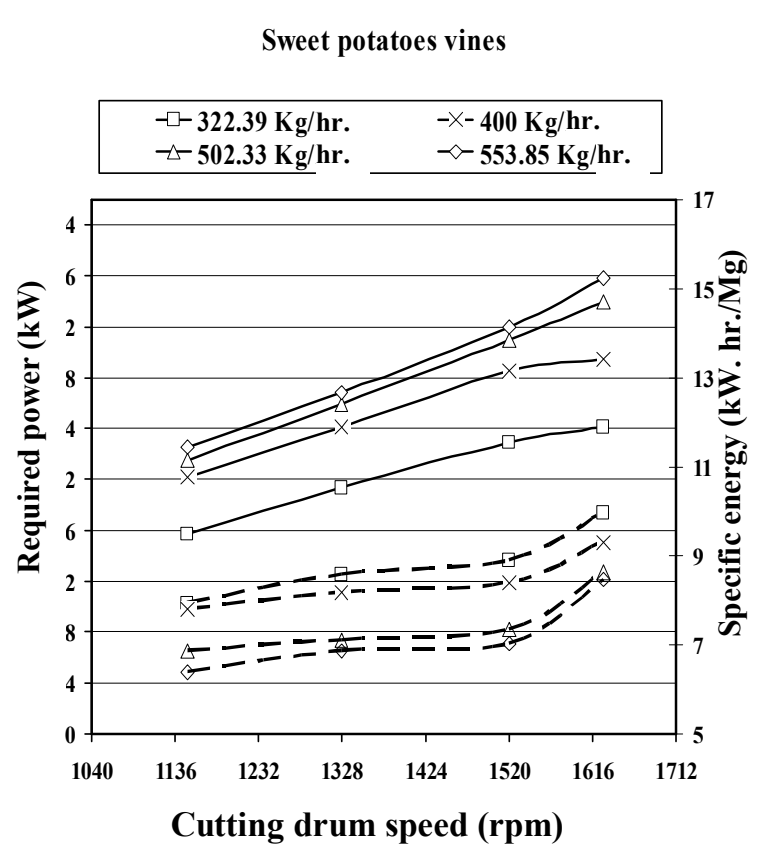

Peanut vines

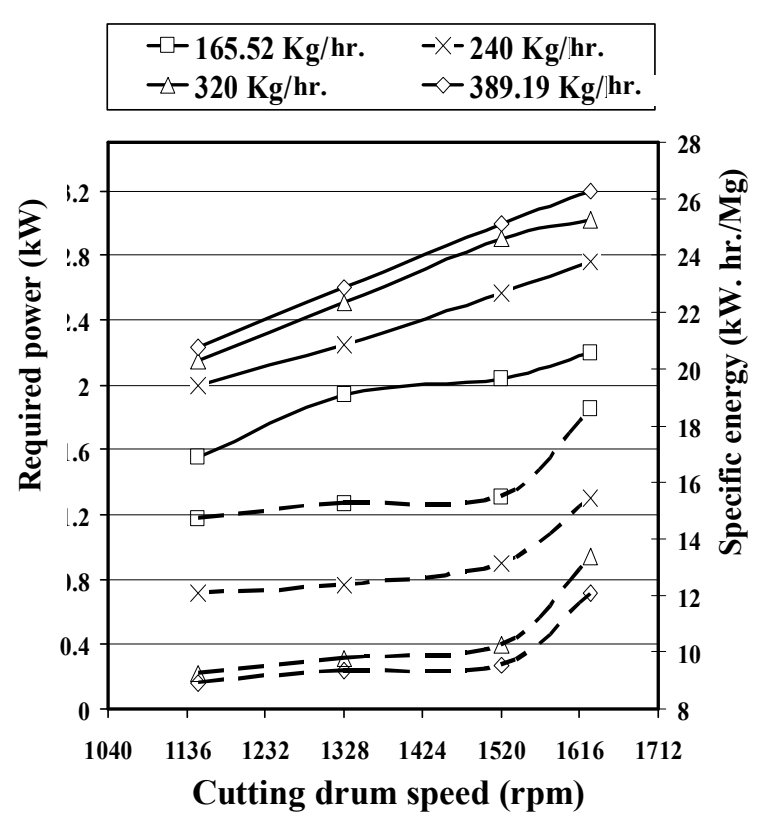

Fig. 3. Effect of cutting drum speed on required power and specific energy at different feed rates for different crop residues 


\section{Operational cost}

Criterion cost

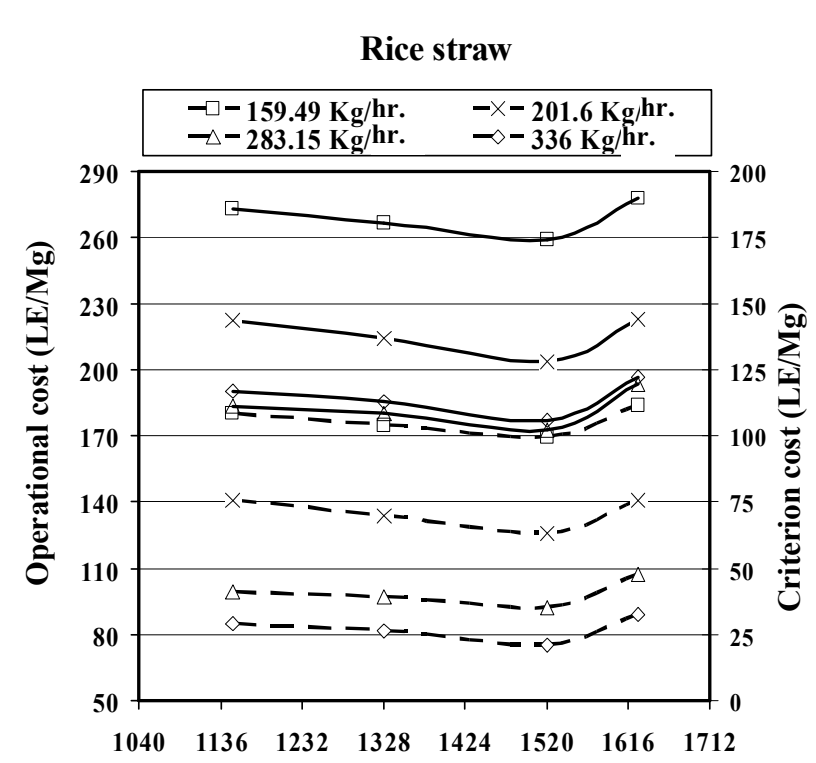

Cutting drum speed (rpm)

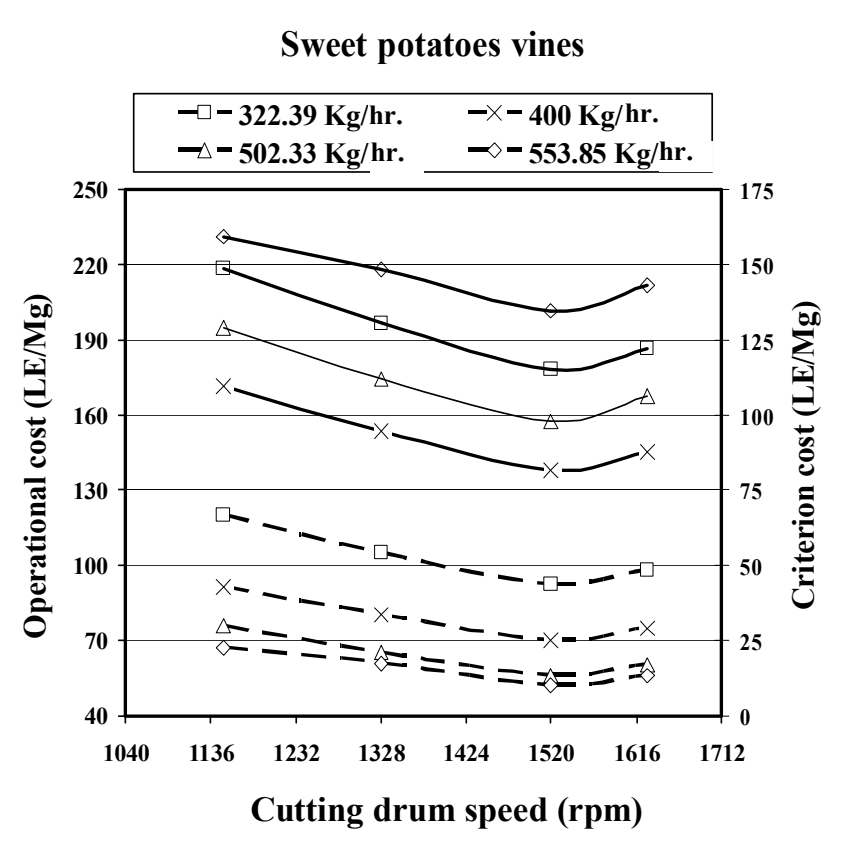

Sweet potatoes vines

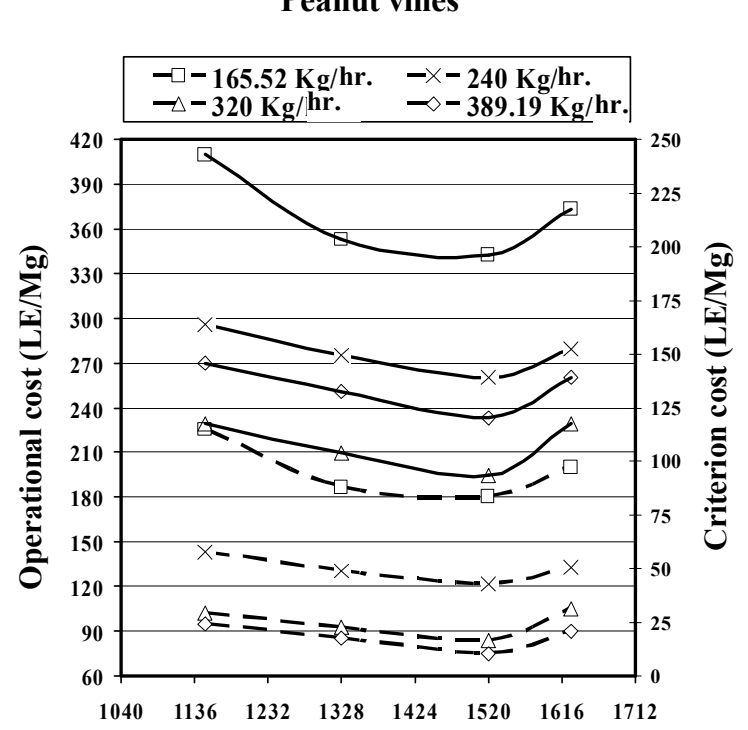

Cutting drum speed (rpm)

Fig.4. Effect of cutting drum speed on operational cost and criterion cost at different feed rates for different crop residues 
As regard peanut vines, results show that increasing drum speed from 1150 to $1520 \mathrm{rpm}$ measured at different feed rates of 165.52, 240, 320 and $389.19 \mathrm{~kg} / \mathrm{hr}$., decreased operational cost from 225.14 to 180.32 , from 143.20 to 121.42, from 102.06 to 84.04 and from 94.67 to $75.33 \mathrm{LE} / \mathrm{Mg}$, also decreased criterion cost from 243.08 to 195.95 , from 163.98 to 138.84 , from 117.74 to 93.32 and from 145.34 to 120.55 $\mathrm{LE} / \mathrm{Mg}$ respectively. The further increase in drum speed more than 1520 up to $1628 \mathrm{rpm}$ measured at the same previous feed rates increased operational cost from 180.32 to 200.42, from 121.42 to 132.67 , from 84.04 to 105.00 and from 75.33 to $89.68 \mathrm{LE} / \mathrm{Mg}$, also increased criterion cost from 195.95 to 217.63 , from 138.84 to 152.40 , from 93.32 to 117.48 and from 120.55 to $138.83 \mathrm{LE} / \mathrm{Mg}$, respectively. Both higher and lower values of cutting drum speed more or less than the optimum value tend to increase operational cost due to the decrease in machine productivity concerning the optimum value.

\section{Conclusion}

The chopping machine was evaluated during cutting rice straw, sweet potatoes vines and peanut vines so as to use the final product to produce animal feed. The experimental results recommended to operate the chopping machine under the following conditions: cutting drum speed of about $1520 \mathrm{rpm}$ corresponding to $(33.41 \mathrm{~m} / \mathrm{sec}$.) for different residues with adjusting feed rates at 283.15, 400 and 320 $\mathrm{kg} / \mathrm{hr}$., for rice straw, sweet potatoes vines and peanut vines respectively.

\section{REFERRENCES}

Awady, M.N., E.Y. Ghoniem and A.I. Hashish (1982). Agriculture comparison between wheat combines harvesters under Egyptian conditions. Res. Bul. Ain- Shams Univ., 13.
El-Iraqi, M. and S. El-Khawaga (2002). Design and test performance of cutting machine for some crop residues. Special Issue for symposium Misr Soc. Agric. Eng., 108-124.

El-Khateeb, H.A. (2007). Effect of engineering parameters of residues chopper on chopper quality. J. Agric. Res., Kafr El-Sheikh Univ., 33 (1): 1-15.

Hunt, D.R. (1983). Farm Power and Machinery Management, Iowa State Univ., Press, $8^{\text {th }}$ Ed.

Ibrahim, D. R. (1983). Wet milling wheat grain. M. Sc. Thesis, Fac. Agric., Mansoura Univ., Egypt.

Lotfy, A. (2003). Development and performance evaluation a machine for cut and throw agricultural. Misr J. Agric. Eng., 20(3):724-736.

Mohamed, T.H., S.M. Younis, M.I. Ghohimy and M.A. Biomy (2001). Development of rice straw chopper. $1^{\text {st }}$ Int. Conf. for manufacturing Agric. Equipment and Machinery $9^{\text {th }}$ Con. Misr Soc. Agric. Eng., 18 (4): 173-200.

Morad, M.M., M.A. Arnaout, O.A. Omar and I.A. Heba (2007). Effect of mechanical chopping and adding different farm residues on soil physical properties and wheat yield. Zagazig. J. Agric. Res., 34 (4): 781-804.

Solomon-Tekeste (2012): A design study of a motor-driven chopper for chopping crop residue and hay. The IUP J. Mech. Eng., 3 : 68-75.

Younis S. M; M. I. Ghoning, M. A. Boyomi and T. H. Mohamed (2002): Techno-Economic Evaluation of a developed field crop residues chopper. The $10^{\text {th }}$ Annual Conf. Misr Soc. Agric. Eng., 16-17 October, 63-80. 


\section{تقيــــم أداء آلــــة لتقطيــــع المخلفــات الزراعيـة \\ منى نصر شعبان رضوان - محمد محمد مراد حسن \\ محب محمد أنيس الثرباصى - محمد محمد بلر}

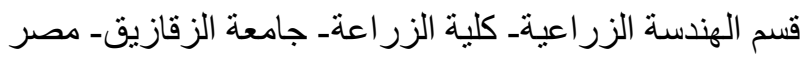

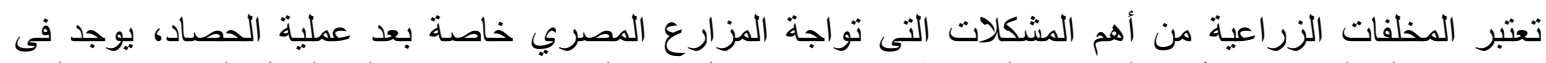

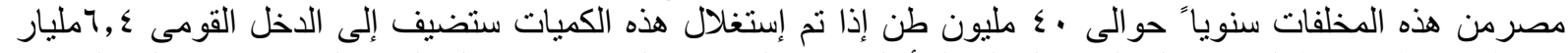

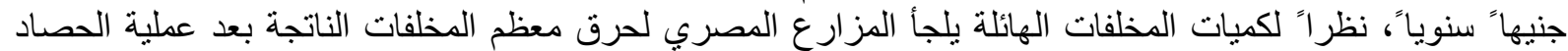

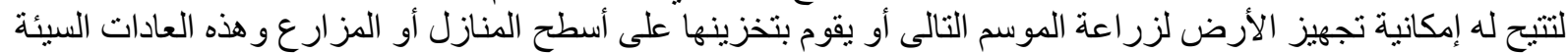

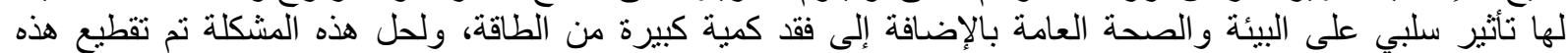

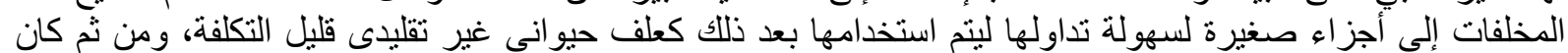

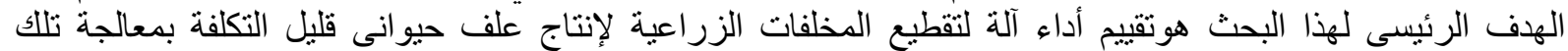

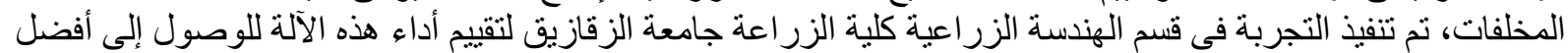

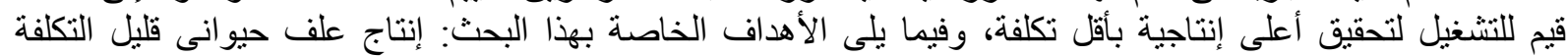

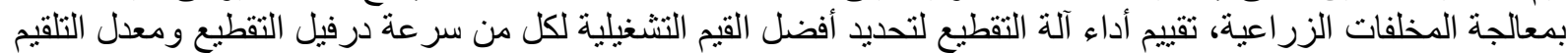

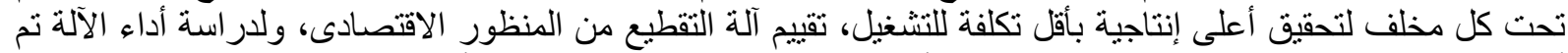

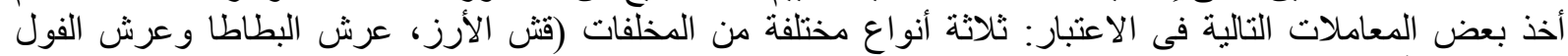

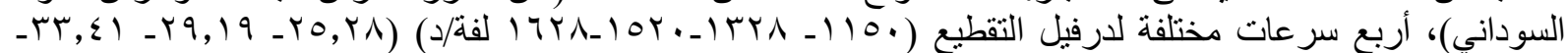
ת

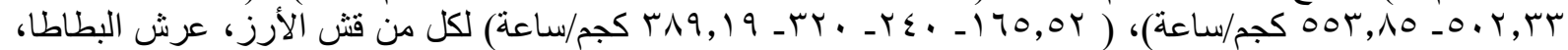

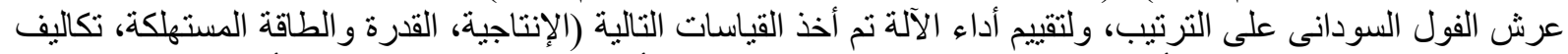

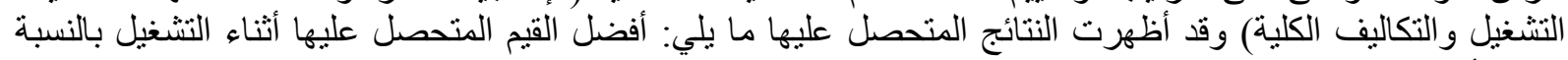

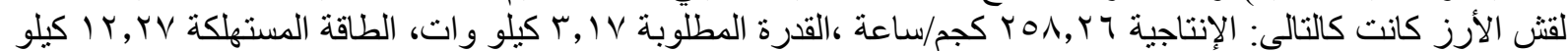

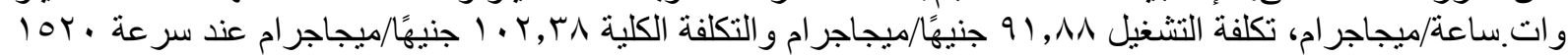

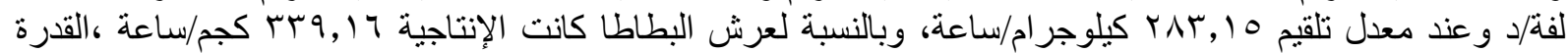

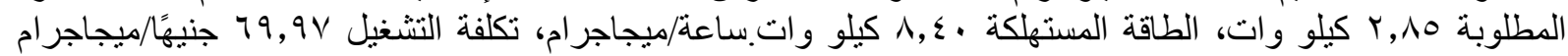

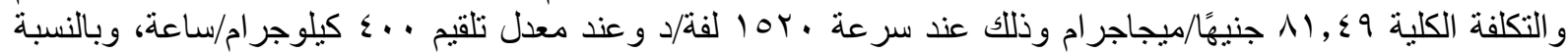

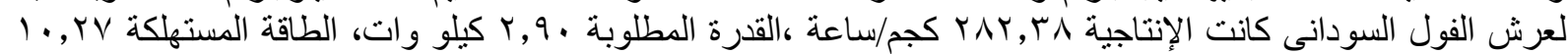

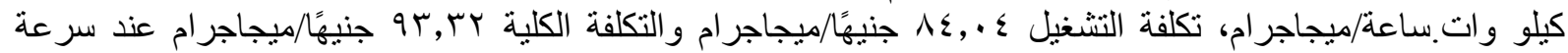

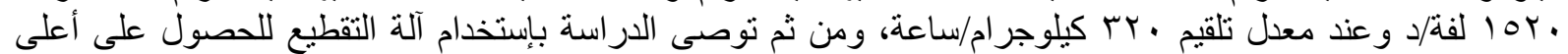

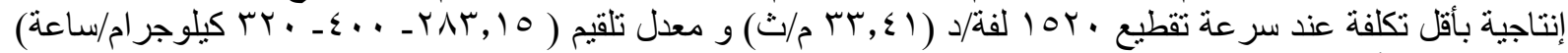

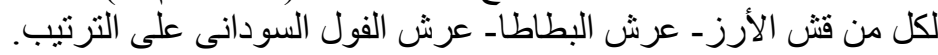

أستاذ ورئيس قسم الهندسة الزر اعبة ـ كلية الزر اعة - جامعة المنصورة. أستاذ الهندسة الزراعية ـ كلية الزر اعة - جامعة الزقازيق. 